\title{
Shifting Private Timberland Ownership in South Carolina: Implications for Management Intensity
}

\author{
John E. Hatcher Jr. ${ }^{1}$, Thomas J. Straka ${ }^{1}$, Richard A. Harper ${ }^{2}$, Tim O. Adams ${ }^{3}$ \\ ${ }^{1}$ School of Agricultural, Forest, and Environmental Sciences, Clemson University, Clemson, USA \\ ${ }^{2}$ Forest Inventory and Analysis, USDA Forest Service, Southern Research Station, Clemson, USA \\ ${ }^{3}$ South Carolina Forestry Commission, Columbia, USA \\ Email: tstraka@clemson.edu
}

Received August 18 ${ }^{\text {th }}$, 2012; Revised September 20 $0^{\text {th }}$, 2012; Accepted October $5^{\text {th }}, 2012$

\begin{abstract}
Beginning in the late 1970's forest industry timberland gained the eye of financial investors. Diamond International and Crown Zellerbach were early firms that were purchased for the "break-up value" of their timberland. Timberland was perceived as undervalued by investors and made forest industry firms attractive takeover targets. This started a process where forest industry divested of its timberland. Some firms formed separate entities for its timberland base. Acquisitions and mergers became popular in the industry. Some forest industry companies converted to real estate investment trusts, for tax and defensive reasons. Large institutional investors became interested in timberland as means to diversify their portfolios and increase financial performance. Timber management investment organizations developed to manage and procure timberland for these institutional investors. Today little of the forest industry timberland remains with vertically-integrated forest products companies. South Carolina's forest industry timberland decreased by about 800,000 ha since 1993 (or nearly 90\%). This has implications for the state's timber supply. Forest industry timberlands were some of the most productive and intensively managed forests in the state. We address how forest management might change on this timberland and how long-term timber supply might be impacted in the state.
\end{abstract}

Keywords: Industrial Timberland; Timber Investment Management Organization; Real Estate Investment Trust; Timber Supply; Forestry Investment

\section{Introduction}

In 1978 there were 907,000 ha of forest industry land in South Carolina (Sheffield, 1978); by about 1986 forest industry timberland peaked out at just over 1 million ha (Tansey, 1986); and in 1993 there were approximately 930,000 ha of forest industry land in South Carolina (Conner, 1998). The big forest industry companies still owned vast areas of timberland. Since then, that industrial timberland base has decreased by about 800,000 ha or $86 \%$. Westvaco owned 200,000 ha and five companies owned over roughly 100,000 ha each (Egbert et al., 1992). Industrial forest lands started a shift in the late 1970s towards company mergers and acquisitions, institutional investor ownership, and conversion to real estate investment trusts (REITs).

The catalyst began when timberland was identified as an undervalued asset that could be split off from the larger company for a profit (Binkley, 2007). Sir James Goldsmith started the process with the acquisitions of Diamond International and Crown Zellerbach. By the early 1980s a climate of hostile takeovers emerged and forest industry companies developed defensive strategies like limited partnerships holding the timberland assets (Binkley et al., 1996). Table 1 shows the dramatic decrease in forest industry timberland from 1991 to 2012.

The rise of timberland investment management organizations (TIMOs) also started in the 1970s with several pension funds diversifying into timberland investments (Binkley, 2007). By the 1980s the transition to TIMO ownership from forest industry land or conversion of forest industry land to REITS was in full swing. The traditional rationale for holding industrial timberland was future raw material supply (timber supply security), timberland investment return, tax advantages, and some control over the timber costs (Yin et al., 1998).

Table 1.

Area of timberland owned or controlled by selected large forest industry companies, South Carolina, 1991 (Egbert et al., 1992, updated).

\begin{tabular}{lccc}
\hline \multicolumn{1}{c}{ Company } & 1991 ha & 2007 ha & 2012 ha \\
\hline Westvaco Corp. & 202,000 & 159,000 & 131,500 \\
Bowater Corporation & 150,000 & 800 & 0 \\
Georgia-Pacific Corp. & 124,000 & 0 & 0 \\
International Paper & 115,000 & 25,000 & 0 \\
Champion International & 96,000 & 0 & 0 \\
Canal Industries Inc & 59,000 & 0 & 0 \\
Union Camp Corp & 36,000 & 0 & 0 \\
Federal Paper Board. & 30,000 & 0 & 0 \\
Willamette Industries & 28,000 & 0 & 0 \\
Sonoco Products Co. & 24,000 & 23,000 & 23,000 \\
\hline
\end{tabular}


Changes in tax laws fueled industry divesting of timberland. The Employee Retirement Income Security Act of 1974 (ERISA) encouraged pension funds to invest in timberland (Binkley, 2007) and the 1986 Tax Reform Act removed a capital gains tax advantage for industrial ownership (Yin et al., 1998). Irland and Howard (1989) saw the increased activity in timberland ownership exchange resulting from issues like fiber supply control, timberland as collateral, timberland for investment, and timberland as a source of capital. As this transition played out, several major mergers and acquisitions took place in the industry (Diamond et al., 1999). Many of these impacted South Carolina timberland.

The main reasons forest industry sold timberland were 1) the need to increase shareholder returns; 2) the need to reduce debt, especially those firms that acquired other firms with debt financing; 3) firm restructuring to increase tax efficiency using REITs and subchapter S corporations; 4) tax strategies that allowed for reduced capital gains taxes; and 5) recognition that timber supply security was not as important as assumed in the past (the market would supply plenty of timber and land could be sold with timber supply agreements for the mills) (Clutter et al., 2005).

Investors in these timberlands saw an asset that 1) produced strong long-term financial returns; 2) had a low correlation with other asset classes (stocks and bonds) and thus reduced overall investment risk; 3) provided a good hedge against inflation; and 4) provided tax advantages (Fasano \& Straka, 2009). Gunnoe and Gellert (2011) reported TIMO timberland ownership approaching 10 million ha and REIT timberland ownership approaching 6 million ha.

\section{Impact on South Carolina Forests}

These trends are pronounced in South Carolina. Forest industry had a $\$ 17$ billion economic impact on the state's economy in 2006. Forest industry has traditionally maintained a large timberland base. Table 1 shows the forest industry timberland base in 1991, 2007 and 2012. Major transitions took place over those 16 years. Mergers and acquisitions combined many of the companies and eventually the remaining companies sold off much of that timberland base.

Table 1 identifies the integrated forest products companies that sold off timberland over the last twenty years. International Paper Company sold most (85\%) of its United States timberland in 2006 in the largest private forestland sale in national history (Reuters, 2006). Smaller transactions, sales of land for environmental and conservation purposes and higher and best use transactions accounted for the rest. This transaction involved a huge amount of South Carolina timberland as mergers and acquisitions greatly expanded International Paper's timberland base in the decade prior to the sale. International Paper acquired Federal Paper Board in 1996 (Gilpin, 2005), Union Camp Corporation in 1999 (Wayne, 1998), and Champion International Corporation in 2000 (Deutsch, 2000). Georgia-Pacific Corporation separated its paper and timber businesses in 1997 forming The Timber Group with separate shareholders to manage the timberland investment (Associated Press, 1997). Plum Creek, a REIT, eventually acquired the assets of The Timber Group in 2000 (Georgia-Pacific Corporation, 2000). Bowater sold off most of its South Carolina timberlands in the late 1990s and early 2000s (Seabrook, 2003).

This transition of industrial timberland to corporate ownership is evident in the USDA Forest Service, Forest Inventory and Analysis (FIA) data estimates (USDA, 2012). Figure 1 shows the decrease in industry timberland and increase in corporate timberland since 1993 for the state. Figures 2-4 show the same pattern for the southern coastal plain, northern coastal plain, and Piedmont inventory units of the state, respectively. While industry land is clearly defined on FIA plots, the corporate ownerships include TIMOs, REITSs, and other corporate ownerships such as Limited Liability Company (LLC), partnerships, associations, and clubs. The data were filtered to exclude the obvious unincorporated local partnerships, associations, clubs and Native American ownership, but included all other corporate ownerships as noted in the South Carolina public records, including TIMOs and REITs. Of course, not all land was sold to corporations-some was purchased by individuals

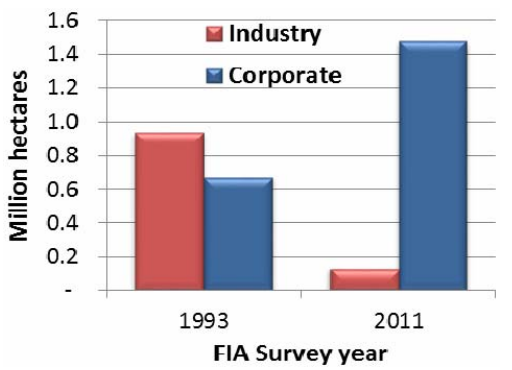

Figure 1.

South Carolina forest industry and corporate timberland in 1993 and 2011 (USDA Forest Service, 2012).

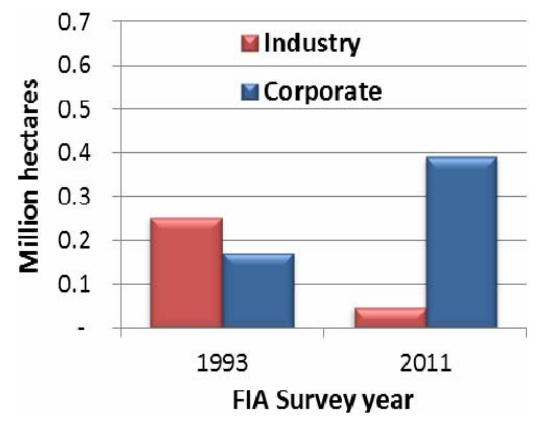

Figure 2.

South Carolina FIA Unit 1 (Southern Coastal Plain) forest industry and corporate timberland in 1993 and 2011(USDA Forest Service, 2012).

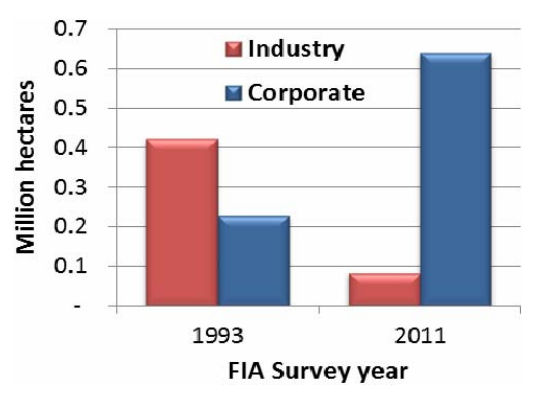

Figure 3.

South Carolina FIA Unit 2 (Northern Coastal Plain) forest industry and corporate timberland in 1993 and 2011(USDA Forest Service, 2012). 


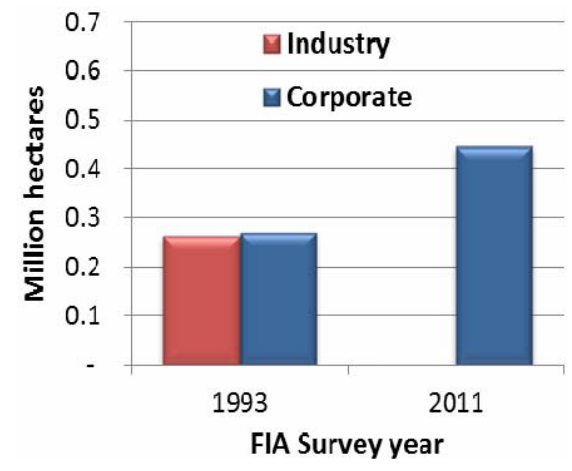

Figure 4.

South Carolina FIA Unit 3 (Upcountry or Piedmont) forest industry and corporate timberland in 1993 and 2011(USDA Forest Service, 2012).

or other industry, and property transfers occurred between corporate and individual ownerships. However, Figures 1-4 illustrate the dramatic divestitures that occurred by the forest industry since 1993.

Across South Carolina, the forest industry divested almost 800,000 ha over the last 15 years and currently is holding less than 200,000 ha (Figure 1). Certainly, the majority of industry land was transferred to corporate ownership, which increased almost 800,000 ha and has more than doubled in area since 1993. About half of the corporate gain (roughly 400,000 ha) occurred in the Northern Coastal Plain which totals almost 650,000 ha. More than $60 \%$ of the remaining industry timberland remains in this area with a total of around 80,000 ha. There are almost 400,000 ha of corporate timberland in the Southern
Coastal Plain with only 50,000 ha of industry land. In the Piedmont, there is a small amount of forest industry land remaining and about 450,000 ha in corporate ownership.

The pattern of forest industry land in South Carolina was centered on the coastal plain and the upper Piedmont. As would be expected, that same pattern exists now for corporate ownership in South Carolina, showing that much of the forest industry land ended up in institutional investor and REIT ownership. Figure 5 illustrates this pattern.

\section{Forest Management Implications}

The new managers of the majority of corporate timberland are the TIMOs and REITs. TIMOs do not own the timberland, but manage it for the institutional investors and REITs are organized to allow timberland owners to avoid "double taxation" (paying taxes on both earnings and dividends). Most institutional timberland owners are tax exempt entities, so tax issues are not relevant to them. Also, they usually do not own processing facilities, so supply issues are of less concern. A big difference between institutional timberland owners and traditional forest industry is that institutional owners can value timberland using "mark to market;" that means they value timber at market value (not book value like forest industry). They use financial models to manage their timber and usually manage on a 10 - 15 year planning horizon. They are most concerned with investor returns. REITs are publicly-traded, so generating earnings to pay dividends to shareholders is essential. Thus, harvest levels (cash flows) are the focus (Browne, 2001).

Browne (2001) contrasted TIMOs, REITs, and traditional forest industry in terms of key characteristics. How will ownership change affect long-term management, management intensity, and management objectives?

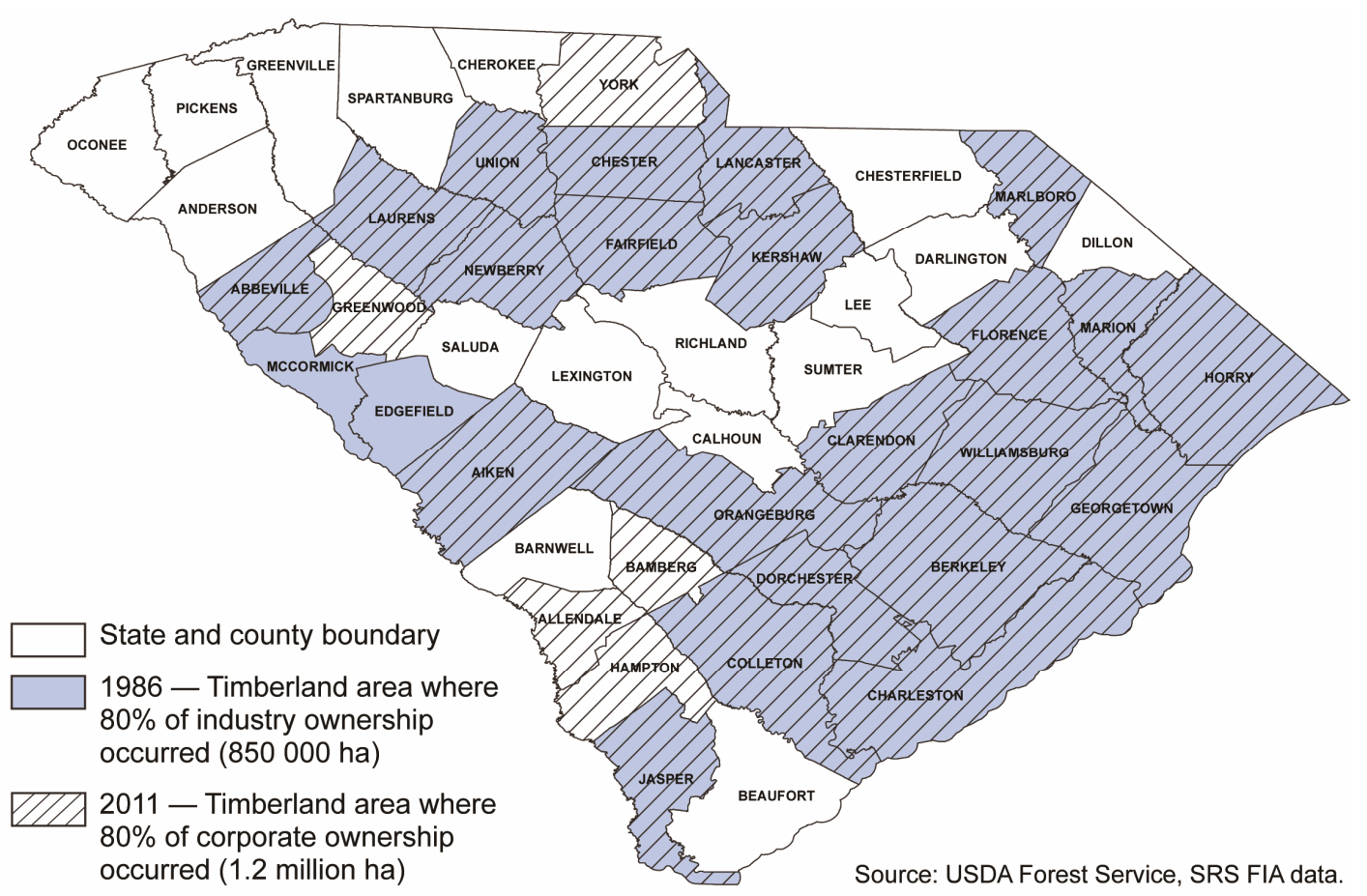

Figure 5.

Forest industry timberland ownerships in 1986 and corporate timberland ownership in 2011 in South Carolina showing geographical overlap. 
Timber rotation. Forest industry manages on rotations that produce the products its mills need. Typically, pulpwood is grown on short rotations and sawtimber rotations are longer. Timber supply pressures can shorten or lengthen rotations to accommodate immediate mill demands. Industry does use sustainable forest management to protect its wood supply. TIMOs and REITs will manage on rotations that maximize financial return, as they are evaluated on financial performance. Sustainability makes financial sense, so it is the norm for both industry and corporate ownerships.

Silvicultural intensity. Forest industry uses intensive forest management to maximize financial return and to produce the most raw material per ha annually. While intensive forestry is the norm on industry land, capital constraints sometimes limit silvicultural options. TIMOs and REITs also manage for maximum financial returns. REITs must produce cash flows to pay periodic dividends. Consequently, REITs must consider cost effectiveness over intensive forest management options and often forego the short-term cost.

Conversion of forestland. Forest industry often looks at its timberland as a crucial timber supply source. However, if the company's accountant, not the forester, is the decision maker, raw material supply often becomes less important. Some firms actively develop the land base for highest and best use and properties are often converted to non-forest uses. Both TIMOs and REITS are profit-motivated and will not hesitate to convert property to its highest and best use.

Stability/long-term ownership. Forest industry has historically taken a long-term view of timberland. Mergers and acquisitions have influenced that view, especially when the debt structure changes. As discussed above, industry has focused more toward divesting their timberlands and often rapidly after acquisition or merger. TIMOs are required to work in 10 - 15 year time frames. When land turns over within a TIMO, it is often purchased by another TIMO. So there is some stability within the investment class. REITs are stable land holders with a long-term perspective. They are under less pressure to sell land for short-term needs.

Protecting sensitive lands. Forest industry was raw material-oriented. That gave them little incentive to divest their land base. However, they have placed an emphasis on donating environmentally-critical lands or selling them at bargain prices for the tax write-off. They also have used conservation easements to protect sensitive lands. TIMOs and REITs are obligated to investors or shareholders to maximize financial returns. So they have little flexibility to donate or sell land for less than fair value. However, environmentally-sensitive land is often hard to manage and pose operational problems. So there is an incentive for them to divest these tracts, but usually if full value can be obtained.

Research. Forest industry desires to maximize raw material production and has an incentive to invest in forestry research. It has been an active partner in forestry research cooperatives and its own research programs. TIMOs have a shorter planning horizon and have less of an inventive than traditional forest industry to invest in research. Like forest industry, REITs have a longer planning horizon and can be expected to invest in research.

Landscape planning management plans. Forest industry has a long history of disciplined management supported by ample capital and professional staff and can be expected to integrate productive landscape-level schemes into their efforts. TIMOs have a shorter planning horizon and do not tend to purchase lands with environmental issues. So landscape-level planning is not as likely on their lands. REITs have the ability to choose lands that do not pose environmental concerns, but they do long-term planning. Thus, some landscape-level planning is accomplished.

Clutter et al. (2005) noted that a potential problem resulting from timberland ownership changes encourages forest fragmentation and parcelization as TIMOs and REITs take advantage of income-producing sales of developable real estate. As land transactions take place, often the highest and best use timberlands are separated out for real estate development. Forest parcelization can result in smaller tract sizes and increased forest management costs due to the loss of economies of scale and reduced long-term timber supply.

Fire suppression is a good example of unintended consequence from timberland ownership changes (Clutter et al., 2005). Forest industry was very proactive in wildfire suppression activities, generally investing in wildfire suppression equipment and trained wildfire suppression crews. TIMOs rely on forestry consultants for most on-ground forest management activities and do not invest in equipment or forestry labor crews. State wildfire control organizations had significant cooperation in wildfire suppression activities provided by forest industry; that is not the case today.

\section{TIMO/REIT Ownership in South Carolina}

Who are the TIMOs and REITs that own timberland in South Carolina? Of the ten forest industry companies surveyed in 1991, Sonoco Products Company and MeadWestvaco are currently the only forest product firms holding significant timberland in South Carolina (Table 1). Currently, Sonoco controls 23,000 of the 24,000 ha held in 1991 . Sonoco's dispositions resulted from economy of scale issues and involved numerous private entities (personal communication, Ronnie Byrd, 25 June 2012).

Table 2 shows the approximate current holdings of the major TIMOs and REITs. It shows a diverse group of corporate owners with large timberland holdings, very similar in distribution to forest industry back in 1991. Since 1991, MeadWestvaco has disposed of approximately $60,000-80,000$ ha of its 202,000 ha to numerous individuals and organizations, including the sale of 14,200 ha to Forest Investment Associates (FIA) in 2009 (personal communication, J. E. Sokol, 26 June 2012). FIA also now controls approximately 40,500 ha of timberland formerly owned by International Paper.

The data in Table 2 are our best estimates. Some TIMOs are hard to track in terms of areas managed. For example, the former Wachovia Timberland Investment Management became RMK Timberland Group and is now Regions Timberlands Group. Some TIMOs are very "tight-lipped” concerning timberland ownership area. Regions is one of those. We know that in 1999 (Lutz, 1999) and 2001 Regions acquired about 113,300 ha of timberland from Bowater. However, as is the reporting custom, the combined area was reported as being in South Carolina, North Carolina, Georgia, and Tennessee. Based on mill location, much of this acquisition must have been in South Carolina. Another complication is that often one purchaser is purchasing for different investment groups along with itself. We also know that Regions Timberland likely had no other timberland transactions in South Carolina from 2000 to 
Table 2.

Estimated timberland area owned in South Carolina by major investment group, 2012.

\begin{tabular}{cc}
\hline Investment Group & Area (ha) \\
\hline Resource Management Service & 102,625 \\
Forest Investment Associates & 54,750 \\
Plum Creek & 42,200 \\
Hancock Timber Resource Group & 38,450 \\
Regions Timberland Group & 27,000 \\
Timberland Investment Resources & 14,750 \\
American Timberlands & 8100 \\
Timbervest & 4590 \\
The Campbell Group & 4330 \\
Crescent Resources & 3040 \\
\hline
\end{tabular}

mid-2010 (Harris, Baldwin, \& Siry, 2010). Thus, Table 2 data are based on reasonable assumptions and the best published or personal data available.

International Paper Company divested itself of most of its timberland in 2006 in a sale to an investment group led by Resource Management Service, with a separate sale to Timberstar. Typical of large-scale timberland transactions, International Paper secured a 20-year fiber supply agreement as part of the transaction (International Paper Company, 2006). Figure 6 uses International Paper Company to illustrate the merger and acquisition activities of the 1990s and Figure 7 to illustrate the subsequent disposition of timberland.

Fiber and wood supply agreements developed between corporate ownerships and large wood product manufacturers as important components of large-scale timberland transactions. Both the buyer and seller benefit from these arrangements. The seller secures a guaranteed long-term fiber supply for their mill. The buyer secures a guaranteed market for the timber from the purchased timberland. Some large forest consulting firms have developed wood flow groups to plan and manage these fiber agreements to ensure proper harvest scheduling (American Forest Management, 2012). Another transaction with MeadWestvaco involved a 60-year wood supply agreement (Gerhardt, 2003).

One review of 17 timberland transactions found that $41 \%$ contained long-term fiber or wood supply agreements. Another common feature for these transactions is the inclusion of conservation easements. Nearly $30 \%$ of the timberland sales included conservation easements designed to protect conservation and recreation values. These easements can add substantial value to the sales (Mendell, 2007).

MeadWestvaco took a slightly different approach to divesting itself of timberland. Self-sufficiency, or retaining all company timberland, was considered one extreme that would be an internal focus on mill integration and costs. The other extreme was a $100 \%$ timberland divestiture that would be an external focus on profit and cash flow. MeadWestvaco chose the "middle ground" and reduced timberland in the Unites States from 1.25 million ha to 850,000 ha (Gerhardt, 2003).

In 2008 MeadWestvaco established a Community Development and Land Management Group to "create and manage a

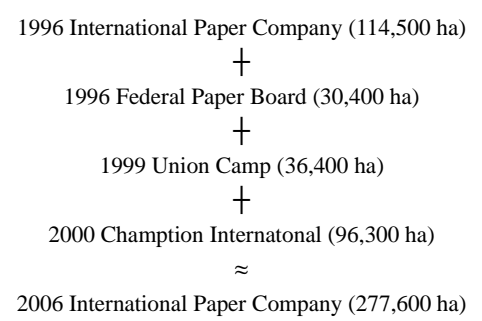

Figure 6.

International Paper Company merger and acquisition timberland growth, 1996-2006.

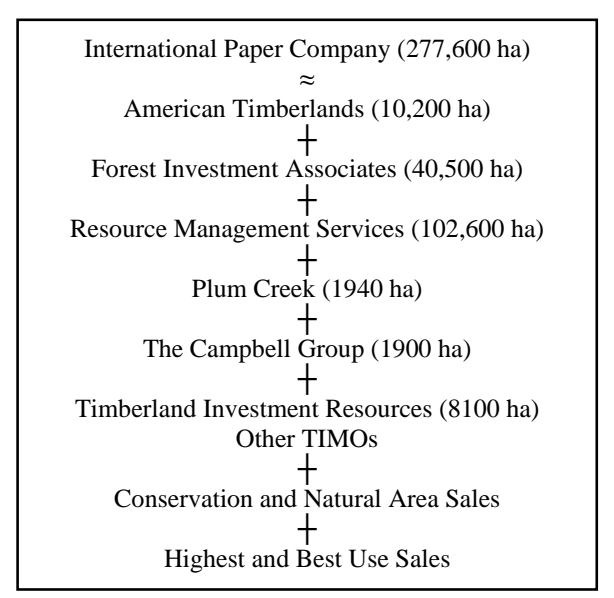

Figure 7.

International Paper Company Timberland disposition beginning in 2006 (ha to not sum due to various other transactions).

land portfolio capable of generating sustainable earnings and cash flow and maximizing shareholder value" (McDermott, 2011). Thus, the goal was timberland divestiture, but to maximize return from the land over time. In 2009 they sold about 10,100 ha in South Carolina to two investment groups (Parker, 2009).

One large MeadWestvaco development, East Edisto, is about 30,000 ha in size and will be developed over decades with a mix of businesses, schools, and conservation areas (McDermott, 2011). This is a "smart growth" development. Smart growth developments have been a part of the US planning lexicon for over a decade, and an ever-increasing range of organizations have come forward to endorse principles (Ye et al., 2005). Although broadly defined, they encompass six broad areas: comprehensive growth planning mixed land use zoning, design and planning for increased residential density, design for street connectivity, innovation in water infrastructure provision, and enhancement of public service facilities, including recreational areas (Daniels \& Lapping, 2005). Moreover, the planning of such communities is deemed to be "smart" based on its utilization of existing infrastructure and potential contributions to reduce energy consumption; its inclusiveness and inherently regional logic and character; and integrating housing, economic development, and transportation elements.

Other significant transactions involving REITs and TIMOs include Bowater's sale of 38,500 ha in the Piedmont and Northern Coastal Plain to Hancock Timber Resources (personal 
communication, B. J. Keefer, 8 June 2012); Plum Creek’s acquisition of 39,300 ha dispersed across the state from Georgia-Pacific (personal communication, C. Hall, 7 June 2012); and The Campbell Group's acquisition of approximately 4050 ha of timberland from Georgia-Pacific and International Paper (personal communication, J. Shore, 7 June 2012).

Numerous small private equity firms have also been involved in the acquisition of industrial timberlands over the last decade. Crescent Resources, a real estate development group based out of Charlotte, NC, acquired 3000 ha in the Piedmont and Northern Coastal Plain from Bowater (personal communication, J. Short, 5 June 2012) and American Timberlands Company acquisition 8100 ha in Horry County from International Paper (American Timberlands Company, 2012).

Inspection of Tables $\mathbf{1}$ and $\mathbf{2}$ reveals that timberlands currently held by investment groups account for only a portion of the timberlands once owned by forest industry. This is in part due to the frequency of transactions that have occurred over the last few decades between industry, individuals, and other investment groups. For example, approximately 28,000 of the 69,000 ha held by Plum Creek were once controlled by the California Public Employees' Retirement System, who in turn, initially acquired the majority of the timberland from International Paper Company (Cecil Hall, personal correspondence, 11 June 2012).

\section{Conclusion}

Over the last few decades, changes in tax laws and the need to improve corporate structure forced many forest industry companies to divest of their timberlands. Investment groups viewed this as an opportunity to invest in an asset class that would provide strong long-term financial returns, was less volatile than other investment vehicles, provided a good hedge against inflation, and provided tax advantages. As a result this shift in ownership in South Carolina is demonstrated in the USDA Forest Service, Forest Inventory and Analysis data estimates. Estimates from 1993 and 2011 show that corporate ownerships now control over 1.4 million ha, while forest industry holds less than 200,000 ha (Figure 1). Although these new owners share many of the same management objectives as forest industry companies, the need to satisfy their investor's portfolio requirements may result in increased forest fragmentation and parcelization, and fire suppression issues across the state.

\section{Acknowledgements}

This material is based upon research supported by NIFA/ USDA, under project number SC-1700396.

\section{REFERENCES}

American Forest Management (2012). AFM wood flow. URL (last checked 5 July 2002).

http://www.americanforestmanagement.com/contents.cfm?p=woodfl ow

American Timberlands Company (2012). American Timberlands Company, Horry County. URL (last checked 8 July 2012).

http://www.americantimberlands.com/horry-county

Associated Press (1997). Georgia-Pacific to separate timber business. The Augusta Chronicle, 18 September 1997.

Binkley, C. S. (2007). The rise and fall of the timberland investment management organizations: Ownership changes in US forestland. In 2007 Pinchot distinguished lecture (p. 12). Milford, PA: Pinchot Institute for Conservation.

Binkley, C. S., Raper, C. F., \& Washburn, C. L. (1996). Institutional ownership of US timberland: History, rationale, and implication for forest management. Journal of Forestry, 94, 21-28

Browne, M. (2001). Changing ownership patterns: An overview of institutional ownership and resulting opportunities. In N. E. Block, \& V. A. Sample, Industrial timberland divestitures and investments: Opportunities and challenges in forestland conservation (pp. 8-23). Milford, PA: Pinchot Institute for Conservation.

Clutter, M., Mendell, B., Newman, D., Wear, D., \& Greis, J. (2005). Strategic factors driving timberland ownership changes in the US south. Athens, GA: Center for Forest Business, University of Georgia; USDA Forest Service; Southern Group of State Foresters.

Conner, R. C. (1998). South Carolina's forests, 1993. Asheville, NC: USDA Forest Service, Southern Research Station.

Daniels, T., \& Lapping, M. (2005). Land preservation: An essential ingredient in smart growth. Journal of Planning Literature, 19, 316329. doi:10.1177/0885412204271379

Deutsch, C. H. (2000). International paper offers $\$ 6.2$ Billion for champion. The New York Times, 26 April 2000.

Diamond, J., Chappelle, D. E., \& Edwards, J. D. (1999). Mergers and acquisitions in the forest products industry. Forest Products Journal, 49, 24-36.

Egbert, C. D., Morris, J. A., Nodine, S. K., \& Straka, T. J. (1992). Forestry and South Carolina's forest resources-Their economic importance. Clemson: Clemson University Cooperative Extension Circular 675 .

Fasano, G. A., \& Straka, T. J. (2009). Timberland investing for financial planning. Journal of Financial Planning, 22, 56-63.

Georgia-Pacific Corporation (2000). Plum Creek Timber Company to merge with Georgia-Pacific Corporation's the Timber Group. Georgia-Pacific News, 18 July 2000.

Gerhardt, D. W. (2003). MeadWestvaco’s perspective on survival in the global economic. URL (last checked 5 July 2012). http://www2.sfasu.edu/forestry/sevices/proceedings/dwgTexas13103 A.pdf

Gilpin, K. N. (1995). International paper plans to buy federal paper board. The New York Times, 7 November 1995.

Gunnoe, A., \& Gellert, P. K. (2011). Financialization, shareholder value, and the transformation of timberland ownership in the US. Critical Sociology, 37, 265-284. doi:10.1177/0896920510378764

Harris, T., Baldwin, S., \& Siry, J. (2010). United States timberland markets 2000 to mid-2010: Transactions, values, \& market research. Athens, GA: Timber Mart-South.

International Paper Company (2006). International paper agrees to sell 5.1 million acres of US forestland for $\$ 6.1$ billion. Stamford, CT: International Paper Company.

Irland, L. C., \& Howard, T. E. (1989). Innovative forms of timberland ownership: What are the driving forces? The Consultant, 34, 32-37.

Lutz, J. (ed.). (1999). Southern timberland activity. James W. Sewall Company Timberland Report, 1, 2.

McDermott, J. (2011). MeadWestvaco 3-year old real estate unit looks to cover all bases. Charleston, SC: The Post and Courier.

Mendell, B. C. (ed.). (2007). Timberland ownership and forest industry changes in the US northeast. James W. Sewall Company Timberland Report, 9, 1-3.

Parker, M. (2009). MeadWestvaco sells 25,000 acres in S.C. for \$49 M. Charleston Regional Business Journal, 30 April 2009.

Reuters. (2006). International paper to sell most of its forestland. The New York Times, 5 April 2006.

Seabrook, C. (2003). Sale of timber creating a land rush. Chicago Tribune, 23 August 2003.

Sheffield, R. M. (1978). Forest statistics for South Carolina, 1978. Asheville, NC: USDA Forest Service, Southeastern Forest Experiment Station.

Tansey, J. B. (1986). Forest statistics for South Carolina, 1986. Asheville, NC: USDA Forest Service, Southeastern Forest Experiment 


\section{J. E. HATCHER JR. ET AL.}

Station.

USDA Forest Service (N.d.). SRS regional table generator for FIADB/ NIMS. Version 5.1. Knoxville, TN: US Department of Agriculture Forest Service, Southern Research Station.

Wayne, L. (1998). International paper to buy union camp in a \$5 Billion deal. The New York Times, 25 November 1998.
Ye, L., Mandpe, S., \& Meyer, P. B. (2005). What is "smart growth?”-Really? Journal of Planning Literature, 19, 301-315.

Yin, R., Caulfield, J. P., Aronow, M. E., \& Harris Jr., T. G. (1998). Industrial timberland: Current situation, holding rationale, and future development. Forest Products Journal, 48, 43-48. 